\title{
LEAVES IN CLASS: RECENT TEXT EDITIONS OF WHITMAN'S WORK
}

\author{
ED Folsom
}

Walt Whitman, Leaves of Grass and Other Writings. Edited by Michael Moon. Norton Critical Edition. New York: Norton, 2002. lii + 919 pp.

Walt Whitman, Selected Poems. Edited by Harold Bloom. American Poets Project. New York: Literary Classics of the United States, 2003. xxxii +224 pp.

Walt Whitman, Poetry and Prose. Edited by Shira Wolosky. Milford, Connecticut: Toby Press, 2003. xxii +892 pp.

EDITIONS OF WHITMAN's wORK continue to appear with regularityamazon.com now lists nearly fifty editions in print-but those instructors who teach courses on Whitman have tended, in recent years, to use one of a handful of texts: the Norton Critical Edition of Leaves of Grass, which has until now had the advantage of being a facsimile of the authoritative New York University Press Comprehensive Reader's Edition, edited by Harold W. Blodgett and Sculley Bradley; the Library of America Poetry and Prose volume, which has the advantage of offering the complete 1855 Leaves of Grass along with the Deathbed Edition, as well as a very generous selection of prose, including the complete Specimen Days; or Lawrence Buell's Leaves of Grass and Selected Prose (Modern Library, now McGraw-Hill), which has the advantage of a lot of material for a relatively low price (under $\$ 10$ ). Other contenders have appeared in the past few years, including Gary Schmidgall's edition of Selected Poems 1855-1892, presenting Whitman's poems in their firstpublished forms and offering some nice supplementary materials, including Whitman's various comments on Leaves. Some old standby editions-like Malcolm Cowley's "facsimile" edition of the 1855 Leaves (Penguin), James E. Miller, Jr.'s Complete Poetry and Selected Prose (Riverside), Francis Murphy's Complete Poems (Viking), The Portable Walt Whitman (Penguin, about to be issued in a revised version edited by Michael Warner), and Gay Wilson Allen's stripped-down and inexpensive Leaves of Grass (Signet) - continue to be used, even though some have been around now for nearly half a century. The three books under review here add some intriguing twists and new considerations for the instructor shopping for a Whitman text. 
Most significant is the long-awaited revised edition of the Norton Critical Edition of Leaves of Grass. This new version is certainly a serviceable text, but since the Norton Critical Edition has been a staple in many Whitman courses since the 1970 s, I want to take some time to examine this new incarnation in some detail. This is, after all, the first major revision of what the editor, Michael Moon, calls a "venerable" book. Most Whitman scholars have known for years that the revision was in the hands of Moon, author of Disseminating Whitman (1991). Many of us were anxious about what the revisions might bring, because the Norton edition has always held a special place among Whitman texts, even as it existed in an odd textual space-somewhere between a facsimile reprinting of the Leaves of Grass "Comprehensive Reader's Edition" (part of the Complete Writings of Walt Whitman) and an independent textbook (part of the popular and respected Norton Critical Editions series). Until now, Norton has always retained the basic 1965 "Comprehensive Reader's Edition" (CRE) text and critical apparatus and offered it in exact facsimile, maintaining matching pagination for the poetry part of the volume, which was handy since most criticism from 1965 to the present has cited the $C R E$, so students could use the text to easily find passages that were quoted in articles and books about Whitman. One of the first things longtime Norton users will notice about this new edition is that it has been completely reset, so the pagination is now entirely different (the 707 pages of poetry in the $C R E$ have been compressed to 615). One of the real advantages of the Norton text, then-its exact reproduction of the $C R E$ pages - has disappeared. The CRE addenda of "Poems Excluded from Leaves of Grass," "Passages Excluded from Leaves," and "Uncollected Poems" are retained but not updated. This is particularly curious, since many of the passages included under the CRE rubric of "Passages Excluded from Leaves of Grass Poems" are passages from the 1855 Leaves, which are in fact now included in the new Norton, since Moon has chosen to add the entire 1855 Leaves. So, in one section, we have passages we're told have been excluded from Leaves, and, in another, we have those very passages included in the 1855 Leaves, just as, under "Poems Excluded from Leaves of Grass," we find "Great Are the Myths," which we also now find included in its 1855 version. It is this kind of partial revision, leading to internal inconsistencies, that is especially unsettling in the new Norton.

Moon's task here-and it was not an enviable one-was to produce a substantially new Norton Critical Edition while respecting and often deferring to the Bradley and Blodgett CRE. This could not have been an easy job. Almost inevitably, this kind of balancing act fails to produce satisfying results, and there are, to be sure, any number of problems with the new Norton edition. There would seem to have been two clear options in reissuing the Norton text: either maintain the original 
$C R E$ (with all of its quirks and anachronisms) for its historical values and strengths (values and strengths that diminish as soon as the original is altered), or do a major revision, abandoning the $C R E$ and its apparatus to allow for a complete rethinking and updating (thus losing the historical advantage the Norton has long held). Norton chose to straddle the fence, and so now, more than ever, the Norton Leaves inhabits some twilight zone between the old $C R E$ and a new and unrelated text edition. If we look to Moon's brief preface for guidance, we find it creates more problems than it resolves:

The present editor has made no changes in the body of the poetic text, which remains Bradley and Blodgett's "Reader's Edition," based on their still-definitive Leaves of Grass variorum. Owing to changes in printing technology, it has not always been possible to preserve the previous edition's strict adherence to the breaking of the run-on lines precisely as they appeared in the 1891-92 Leaves of Grass. . . .

Where to begin? Somehow, Moon is under the misapprehension that Bradley and Blodgett "based" the CRE on their Variorum Edition, which appeared, he tells us, "from New York University Press in 1965"! Underscoring this error, Moon adds a footnote to Bradley and Blodgett's reprinted original introduction, affirming that the three-volume textual Variorum of Leaves (edited by Bradley, Blodgett, Arthur Golden, and William White) was published in 1965 . But of course the Variorum was in fact not published until 1980 (as Moon finally correctly records in his "Selected Bibliography" in the back of the book). Far from basing the $C R E$ on the Variorum, Bradley and Blodgett actually worked on the $C R E$ as preparation for the Variorum (which they were never able to finish and which had to be salvaged by Golden and White, who finished the project only by jettisoning the plans to include manuscripts and periodical publication of the poems). It does not give readers of the new Norton much confidence when the new editor makes such basic errors of fact in summarizing the history of the book he is editing.

There are other troubling aspects of Moon's preface. He seems remarkably casual about losing Whitman's original enjambed line-breaks, something Bradley and Blodgett were careful to retain; it is difficult to see how he could abandon such a central feature of their work and still claim that he "has made no changes in the body of the poetic text." It is a mystery to this reviewer how "changes in printing technology" have made it impossible to do today what printers in 1965 accomplished with little trouble (all the changes brought about by computer advances would seem to have made it easier to compose pages and render line breaks correctly). Amazingly, while resetting the entire text, the editor and publisher neglected to correct the numerous small errors in the $C R E$ - errors that were noted nearly thirty years ago by William White when checking the $C R E$ in preparation for the Variorum Edition. ${ }^{1}$ This 
means, of course, that no one bothered to check the CRE text against Whitman's original texts (which, after all, remain the "authoritative" texts) and, as a result, lingering errors have been set in type all over again.

As mentioned earlier, Moon has decided to add the 1855 Leavesa welcome addition, even though it appears in the volume, oddly, after the Deathbed edition instead of before it - but again, this inclusion raises serious questions, since the 1855 text was not included in either the original CRE or in the Variorum Leaves (where the final published version of each poem serves as the copy text). There is no indication where Moon's 1855 text comes from, but it certainly did not come from Bradley and Blodgett, and so it contradicts once again Moon's assurance that he "has made no changes" to the "poetic text" in the CRE. And as we begin to read the 1855 text in the new Norton, we immediately worry about the reliability of the editing, since the very first line contains an error: "I Celebrate myself". (The capitalized "Celebrate" is Moon's invention, and it is without textual basis: in the original, the entire word is in capital letters, though most editors-including Bradley and Blodgett - simply accept the capitalized "CELEBRATE" as an introductory printing convention and render it in lower case.)

For this reviewer, the most troubling aspect of the new Norton is the reprinting of Bradley and Blodgett's long 1965 introduction to the original "Comprehensive Reader's Edition." For those readers who are not knowledgeable about the complex history of the Collected Writings of Walt Whitman project, this introduction will simply be confusing and very misleading. It is outdated and often inaccurate and has been an embarrassment for decades, but it is even more so now, since it is enlisted to introduce a book that is significantly different from the one it originally introduced. Again, the problems begin in the very first sentence, where Bradley and Blodgett talk about the "Variorum Edition" as if it already existed in 1965 (and Moon, as I've noted, exacerbates the problem by adding the erroneous footnote that moves its publication back fifteen years). At the time, Bradley and Blodgett thought they were much further along on the Variorum than they in fact were, and it would be a number of years before Gay Wilson Allen and the other members of the Advisory Board of the Collected Writings realized how much still remained to be done. One of the key discoveries made during the development of the Variorum was that there were only six editions of Leaves of Grass, not nine as had been previously assumed. But in this 1965 introduction, Bradley and Blodgett still refer to "the successive nine editions." Also in 1965, Bradley and Blodgett believed that they were ready to publish a Variorum Edition that would allow all of Whitman's poetry manuscripts to be "fully represented," and in the introduction they announce that the "rich store" of manuscripts is "spe- 
cifically drawn upon for line-by-line collation in the Variorum Edition." They assure us that the Variorum "deals strictly and exhaustively with all textual variants and evidence that may be derived from the collation of all extant texts of each poem," reporting "all variants of every kind." The Variorum that finally appeared in 1980, however, did not deal with any of Whitman's manuscripts, nor did it include any of the numerous periodical publications of Whitman's poems. Bradley and Blodgett's introduction, in other words, keeps referring to a Variorum Edition that to this day does not exist. To reprint this sad, confusing, and misleading forty-year-old introduction and use it as the entryway into a new version of the book is a travesty. Now, not only does the introduction describe a Variorum Edition that never existed, it also describes a version of the Comprehensive Reader's Edition that no longer exists.

Moon says in his preface, "I have, with a sparing hand, updated some of the $[C R E]$ footnotes, revising and expanding them in view of the massive amount of scholarship on Whitman's book and its contexts that has emerged in the past thirty years." Sparing hand indeed, since only around thirty of the more than one thousand footnotes have been substantively revised (and among those notes left untouched are several that contain wrong information about where various poems first appeared, errors that, again, have been noted for decades). It's difficult to see how this very modest revision of notes takes into account "the massive amount of scholarship" that Moon reminds us has appeared over the past few decades (we're talking about well over a hundred books on Whitman, not to mention thousands of essays and chapters of other books). We are left with far too many leftover CRE citations to outdated scholarship, and thus we are led, again and again, to 1950s and early1960 s readings of poems instead of to the many exciting recent readings informed by New Historicism, cultural theory, queer theory, and all the other developments in interpretive theory and practice that have fueled the profession for the past thirty years. It's not that some of the criticism from half a century ago is not still useful (it is), but Bradley and Blodgett never assumed they were writing critical citations for the ages: they were including in their notes what in 1965 they found to be the most up-todate and useful explications. Most readers of the new Norton will wish that Moon had done a lot more of precisely that for an audience in the 2000 s that now has access to four more decades of criticism.

An example of how Moon has chosen to gently revise the notes is evident in the first three notes to "Song of Myself": he removes Bradley and Blodgett's reference to several critical articles (published from the 1930 s to the early 1960s) that propose structural arguments about the poem and instead substitutes a single reference to Edwin Haviland Miller's 1989 compendium of critical excerpts about the poem (Walt Whitman's "Song of Myself": A Mosaic of Interpretations), telling readers 
they will find "a generous survey of critical opinion" there (though nothing, of course, from the past fifteen years). The next two notes, referring to 1950 and 1951 critical pieces, remain unchanged and unsupplemented. As we look through the rest of the notes to "Song," we find that Moon has changed one CRE 1940s citation to a more recent (1954!) citation; here and there, he tells us that we can find a "sampling of critical response" to a particular section in Miller's Mosaic (but, since Miller includes critical responses to all the sections of "Song," this note could conceivably appear in every section). Except for one reference to an entry in Walt Whitman: An Encyclopedia, the most recent reference in the notes is to Moon's own work.

Occasionally, Moon's updating obfuscates things, as when he changes Bradley and Blodgett's note for "Cuff" ("a Negro") to "African day-name for a male born on a Friday." This definition, Moon tells us, comes from the Dictionary of American Regional English, but the actual $D A R E$ definition is "Orig[inally] a Black man's name; later, any Black male" (Moon seems to have taken one of the possible Africanlanguage etymological origins of the term "cuffy" as a definition, and later, in his notes for "Song of the Answerer," Moon repeats the mistake by applying this definition again to "Cudjoe"). At any rate, the new note hardly helps illuminate the line "Kanuck, Tuckahoe, Congressman, Cuff, I give them the same, I receive them the same."

In his notes on the "Calamus" cluster, Moon is more attentive to recent criticism, offering new citations to Alan Helms, Hershel Parker, John Irwin, Allen Grossman, and Michael Lynch, and when we get to "A Song for Occupations," there's a useful new citation to essays by Alan Trachtenberg and M. Wynn Thomas. When we get to the "DrumTaps" cluster, however, we find not a single new reference, and, throughout the book, major readings of major poems (like Mutlu Konuk Blasing's or Helen Vendler's detailed explications of "When Lilacs Last in the Dooryard Bloom'd") are ignored. On the basis of these notes, we would conclude that nothing of value has been written in the past forty years about "Out of the Cradle" or "Lilacs" or "Passage to India" or "A Song of the Rolling Earth" or other major and frequently explicated Whitman poems. Because Moon does not indicate which notes he has changed or supplemented, it's difficult to decide whether the notes now belong to Moon or to Bradley and Blodgett: at a couple of points Moon distances himself from his predecessors by changing their familiar "we" ("We have restored the comma") to a more distant "This edition restores the comma." Sometimes Moon seems to endorse Bradley and Blodgett's opinions by simply leaving them in place (as when they call Leo Spitzer's 1949 essay on "Out of the Cradle" an "excellent article"), but other times he shuts them up, as when he excises their judgment of "Song of the Exposition" as "one of WW's comparative failures." Here and there Moon makes a grammatical correction (shifting a "which" to a "that") 
or a politically sensitive one (Whitman's brother Eddie moves from "a mental defective" to "feebleminded," and "Indians" become "Native American peoples"). Surely, once the decision was made to abandon the facsimile $C R E$ pages, Norton should have gone all the way and encouraged Moon to do a wholesale revision of the notes. As it is, they feel randomly and sparsely revised and often uneasy with themselves.

Moon has made some other additions, trying to nudge the book towards the comprehensiveness of the Library of America Poetry and Prose volume by including scattered bits of Democratic Vistas and what the back cover calls "generous excerpts" (Moon calls them "substantial") from Specimen Days (it turns out, however, that "generous" and/ or "substantial" means only seven of that book's nearly 250 sections). The CRE has always been the only affordable edition of Leaves with an "album" of Whitman photos and engravings, and these are still included in the new volume, although the reproductions are dark and poorly reproduced. Moon adds a transcription (by Hershel Parker) of "Live Oak, with Moss," Whitman's series of twelve manuscript poems that form the core of the "Calamus" cluster (in this section, the only editorial note, instead of pointing us to dated criticism, points us to a yet-to-bepublished essay). As with the 1855 Leaves, the "Live Oak" addition is useful, but it is not integrated into the book: no notes even guide us back to the particular "Calamus" poems that these manuscript works eventually became.

Moon's most comprehensive revision of the volume is in the "Criticism" section, where he retains from the previous Norton an early review of Leaves written by Whitman, along with pieces by Edward Everett Hale, William Dean Howells, Havelock Ellis, D. H. Lawrence, and William Carlos Williams, and adds illuminating early comments by Fanny Fern, Henry David Thoreau, Anne Gilchrist, Oscar Wilde, and Henry James. Gone are pieces by George Saintsbury, Barrett Wendell, Basil De Selincourt, Van Wyck Brooks, John Cowper Powys, Lewis Mumford, V. L. Parrington, Cesar Pavese, Gay Wilson Allen, Malcolm Cowley, Roger Asselineau, Karl Shapiro, Anthony Burgess, and others, and in their place we have a selection of "recent criticism" by David S. Reynolds, Karen Sanchez-Eppler, Betsy Erkkila, Moon himself, and two of Moon's Johns Hopkins colleagues, John Irwin and Allen Grossman. These selections leave a thirty-year gap between the earlier criticism and the "recent" criticism, and so the flowering of Whitman criticism in the 1960s and 1970s - and the international range of that criticism - is erased. The pieces that are included are all solid contributions, but it is certainly debatable whether, taken together, they effectively represent - any more than the modestly revised notes do - the range of the "massive amount" of scholarship that Moon acknowledges has appeared in the past few decades. 
Harold Bloom's new collection of Whitman's selected poems is handsomely produced and generally unobjectionable. As in most of Bloom's books about Whitman (four miscellaneous collections now in the Chelsea House series), however, there are some nagging errors (Bloom's biographical note in this new volume, for example, refers to "the prose collection November Boughs"). Nearly half the book is taken up with "Song of Myself," presented here in its final version and accompanied by some "early notebook fragments of 'Song of Myself,", seven of them, all reprinted from Emory Holloway's 1920s transcriptions. There is no indication why these particular fragments were chosen (from the many that are available), nor is there any indication why Bloom has depended on Holloway's inaccurate and partial transcriptions instead of going to the original sources. The long-missing notebooks from which Holloway made his transcriptions were recovered in 1995, and the Library of Congress immediately made digital scans available on the Internet. ${ }^{2}$ A glance at the original manuscripts quickly reveals the fallacy of depending on Holloway's cleaned-up transcriptions, especially when we examine Bloom's odd endnotes concerning the transcriptions. He complains at one point about Holloway's editorial fussiness: "'wherever' is followed by '[wherein?],' indicating a conjecture regarding the word Whitman had crossed out at this point in his manuscript." Bloom goes on to announce that "this volume does not print the [wherein?]." Since he has not bothered to examine the original manuscript, however, Bloom does not seem to be aware that Holloway was indicating not a "crossed out" word but rather was indicating that he was unsure whether the word was "wherever" or "wherein" (Whitman's handwriting is very small in this notebook and often hard to decipher). Similiarly, and even more problematically, Bloom notes that "in the Holloway edition 'endure' is followed by '(?)'; in this volume, the question mark is printed without parentheses." So, because he does not realize that Holloway's parenthetical question mark was indicating his lack of certainty about whether Whitman's word was "endure" or some other word (Whitman's script runs off the bottom of the notebook page here), Bloom blithely removes the parentheses and thus adds to Whitman's line a question mark that clearly does not exist in the original. (An examination of the passage in the original indicates that Holloway was right to question his own transcription, since the scrawled word is in fact not "endure" but "undergo"- "Or have you and all the rest combined to see how much I can undergo".)

So, while the impulse to include early manuscript drafts of the poem that would become "Song of Myself" is a good one, its execution in this volume leaves much to be desired. The choice of texts is eccentric, as 
well. Bloom prints the 1855 version of the poem that would eventually be entitled "The Sleepers," but this decision makes his choice of the 1881 "Song of Myself" seem odd, since the manuscripts for "Song" clearly relate much more directly to the 1855 version of the poem than to its significantly revised final version. Bloom's other selections are unremarkable, though he radically de-emphasizes the Civil War poems (including only "The Wound-Dresser" and "Reconciliation").

This volume is part of the Library of America's new "American Poets Project" series. While it is always inspiriting to see a publisher emphasizing poetry, it is unclear to me just how this new series relates to or supplements the main volumes in the Library of America. Bloom's small selection of Whitman's poems sells for $\$ 20$, about what one would pay for the huge Library of America Poetry and Prose hardback volume, which includes the 1855 Leaves, the 1891-92 Leaves, Specimen Days, and many other things as well. Suffice it to say that the big book is the better value.

And, speaking of the big book, Toby Press has issued what at first glance looks like an attractively priced competitor to the Library of America Poetry and Prose. The Toby Press book is also called Poetry $\mathcal{E}$ Prose, and it seems to measure itself against the Library of America volume. At nearly 900 pages, in a large format, but costing only $\$ 7.95$, this collection seems a most attractive combination of size, price, and scope of contents. It is hard, however, not to feel a little uneasy about the book, which must have been fairly hastily assembled, with some major last-minute changes. The Toby Press Review (as the catalog that accompanied the book is called) offers a full-page ad for the Whitman book, but the volume that is described in the catalog is different from the one that was published. The catalog advertises a book called Collected Poetry and proudly announces that the "Toby Edition brings together the earliest and last editions of Leaves of Grass." The actual book, however, now titled Poetry $\mathcal{E}$ Prose, does not contain the 1855 edition and instead gathers a large number of prose pieces (but, surprisingly, not Specimen Days). Shira Wolosky edits the volume, but her short introductionlargely historical and biographical — offers no hint about why she made the choices she made (or why there was a last-minute rethinking of the contents), nor does she discuss the editorial or textual principles that guided her, if in fact she was involved in the editing of the text. The text, we are told on the copyright page, comes from the Electronic Text Center at the University of Virginia, a collection of texts from a wide variety of sources that are encoded at Virginia and made available freely on the Web. The notice tells us that "revisions and corrections were made by 
The Toby Press in March 2003," but what those changes were (and why they were made, and who made them) is nowhere noted. In any case, this is a stripped-down text, with little value added: no annotations, no notes, no bibliography, no portraits.

The Library of America Poetry and Prose is a fairly stripped-down text, too, with its own set of problems and inconsistencies. The original 1982 hardback, originally titled Complete Poetry and Collected Prose, has now been given the same title as the 1996 paperback (Poetry and Prose), even though they are two different texts. The paperback edition is an expanded version of the hardback, containing a valuable collection of "Supplementary Poems" that appeared in neither the 1855 or 18911892 Leaves, both of which are reprinted in this volume. Maddeningly, even the revised version does not print "Old Age Echoes," the posthumous annex to Leaves that contains "A Thought of Columbus." (And neither does the 1992 Library of America Leaves of Grass, yet another offshoot of the Poetry and Prose volume.) The notes to the Poetry and Prose volume, by Justin Kaplan, are sparse and not very helpful, but the texts are reliable, and at over 1400 pages, no other Whitman text compares in terms of the range of materials included. It is an attractive and fairly durable volume, and it sells for under $\$ 20$ (about the same price as the Norton). It lacks portraits, but those are easily available now on the Whitman Archive. ${ }^{3}$ This quirky but reliable Library of America text is now my choice for classes focused on Whitman's work.

The University of Iowa

\section{NOTES}

1 William White, "Errors in Leaves of Grass, Comprehensive Reader's Edition," Papers of the Bibliographic Society of America 68 (October-December 1974), 439-442.

2 See "Poet at Work: Recovered Notebooks from the Thomas Biggs Harned Walt Whitman Collection," http://memory.loc.gov/ammem/wwhtml/, on the Library of Congress American Memory site.

3 See http://www.whitmanarchive.org. 